\title{
GIANT CAVERNOUS MALFORMATION WITH UNUSUALLY AGGRESSIVE CLINICAL COURSE: A CASE REPORT
}

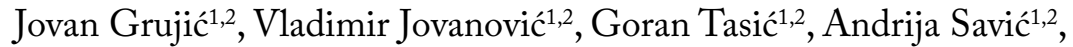

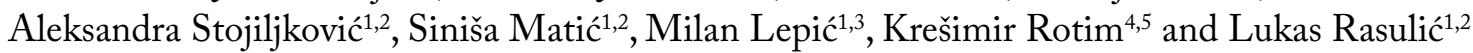 \\ ${ }^{1}$ Faculty of Medicine, University of Belgrade, Belgrade, Serbia; \\ ${ }^{2}$ Department of Neurosurgery, Clinical Center of Serbia, Belgrade, Serbia; \\ ${ }^{3}$ Department of Neurosurgery, Military Medical Academy, Belgrade, Serbia; \\ ${ }^{4}$ School of Medicine, Josip Juraj Strossmayer University of Osijek, Osijek, Croatia; \\ ${ }^{5}$ University of Applied Health Sciences, Zagreb, Croatia
}

\begin{abstract}
SUMMARY - Giant cavernomas (GC) are rare lesions, with less than 50 cases reported so far. Clinical presentation usually involves epileptic seizures and less typically focal neurological deficit, due to repeated hemorrhages and GC mass effect and consequentially increased intracranial pressure. Although individual cases have been reported, due to the rarity and variable imaging appearance, GCs are usually not considered in the differential diagnosis of large hemorrhagic lesions, especially when significant mass effect is present. A 17 -year-old boy presented due to severe headache, right-sided weakness, and slurred speech. Symptoms started three days before with occasional headaches, which intensified gradually. Emergency computed tomography revealed a left frontal massive heterogeneous lesion. Soon after, right-sided hemiparesis and speech impairment progressed, and the patient became drowsy with the slightly dilated left pupil. Emergency surgery was performed, and the lobed grayish lesion was entirely removed. Based on the macroscopic appearance, the surgeon assumed it was a metastasis of melanoma. Histopathologic analysis result was cavernoma. GC should be considered as an option in hemorrhagic lesions, especially in the young age population. Emergency surgery for mass lesions is not uncommon in neurosurgery; however, bleeding cavernomas are usually planned for elective surgery due to the specific approach and complications.
\end{abstract}

Key words: Hemangioma, cavernous; Intracranial hemorrhages; Intracranial pressure; Paresis; Neurosurgery

\section{Introduction}

Cavernomas (cavernous angiomas, hemangiomas) are benign, clearly defined, angiographically occult vascular malformations of the central nervous system, which are composed of vascular channels lined by one-

Correspondence to: Prof. Lukas Rasulic, $M D, P h D$, Faculty of Medicine, University of Belgrade, Department of Neurosurgery, Clinical Center of Serbia, Department of Peripheral Nerve Surgery, Functional Neurosurgery and Pain Management Surgery, Višegradska 26, 11000 Beograd, Serbia

E-mail: lukas.rasulic@gmail.com

Received October 30, 2019, accepted January 16, 2020 layer endothelium separated by matrix made of collagenous tissue and smooth muscles ${ }^{1-3}$. Their prevalence ranges from $0.5 \%$ to $1 \%$ in the general population, and they account for $5 \%-15 \%$ of all intracranial vascular malformations ${ }^{3-10}$. They can be from a few millimeters to a few centimeters in size, usually smaller than $3 \mathrm{~cm}$. The average diameter is about 1.5 $\mathrm{cm}^{1,3,6,10-13}$. Multiple cavernomas can occur, and they are usually familial ${ }^{14}$.

Giant cavernomas (GCs) are rare lesions, with less than 50 cases reported so far ${ }^{15}$. There is no strict consensus on the size threshold for a cavernoma to be considered giant, but typical margin has been defined 
by Lawton et al. at a diameter greater than $60 \mathrm{~mm}^{16}$. The mechanism of GC growth remains uncertain, although a combination of rebleeding and consequential reorganization processes is considered ${ }^{2}$. GCs are usually intra-axial lesions, although some cases were related to the meninges ${ }^{2,3,7-9}$. Familial form of GCs has not been reported ${ }^{6}$.

Usually cavernomas present with epileptic seizures between the second and fourth decade of life, with repeated hemorrhages, and less typically with focal neurological deficit ${ }^{6,16}$. Rarely, cavernomas may be fatal due to the mass effect or hemorrhage in the eloquent area or brainstem. GCs usually act as mass lesions with signs of increased intracranial pressure $(\mathrm{ICP})^{17}$. Although individual cases have been reported, due to the rarity and variable imaging appearance, GCs are usually not considered in the differential diagnosis of large hemorrhagic lesions, especially when significant mass effect is present ${ }^{6,11}$. This is the exact situation where our report of 'bleeding metastasis' with rapid neurological deterioration begins.

\section{Case Report}

A 17-year-old boy presented to the Emergency Centre of the Clinical Centre of Serbia due to severe headache, right-sided weakness, and slurred speech. The symptoms emerged three days before with occasional headache, which intensified gradually. Upon admission, the patient was slightly dysphasic, with right-sided central type facial nerve paresis, and mild brachiocephalic right hemiparesis.

Emergency computerized tomography (CT) revealed a left frontal massive heterogeneous intra-axial expansive lesion with signs of intralesional hemorrhage and striking perifocal edema, leading to incipient subfalcine herniation (Fig. 1).

Initial antiedematous therapy was started, and the patient was admitted to the ward, as his condition was stable with no signs of neurological worsening, for the scheduled surgery. Magnetic resonance imaging (MRI) scan was planned.

In a little while, the patient deteriorated, right-sided hemiparesis and speech impairment progressed, and the patient became somnolent with the slightly dilated left pupil. Emergency CT with angiography showed the signs of repeated intralesional hemorrhage with further perifocal edema spread and severe compressive effect (Fig. 2).

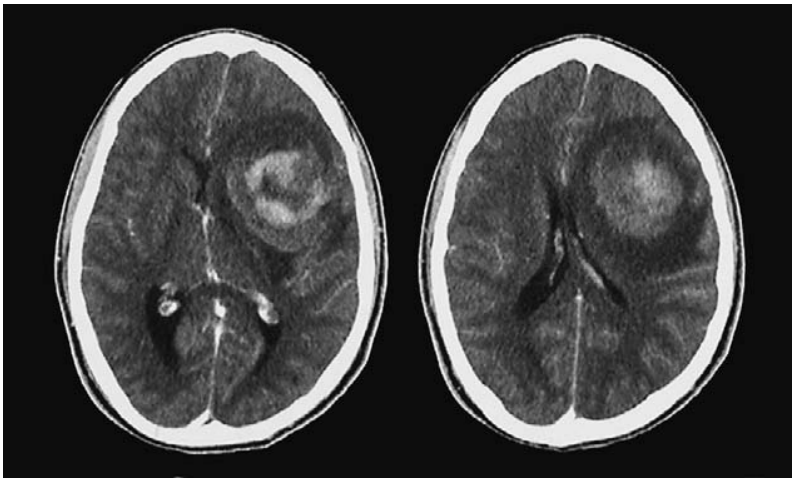

Fig. 1. Initial computed tomography scan: a heterogeneous, mostly hyperdense lesion in the left frontal region with a significant mass effect and midline shift.

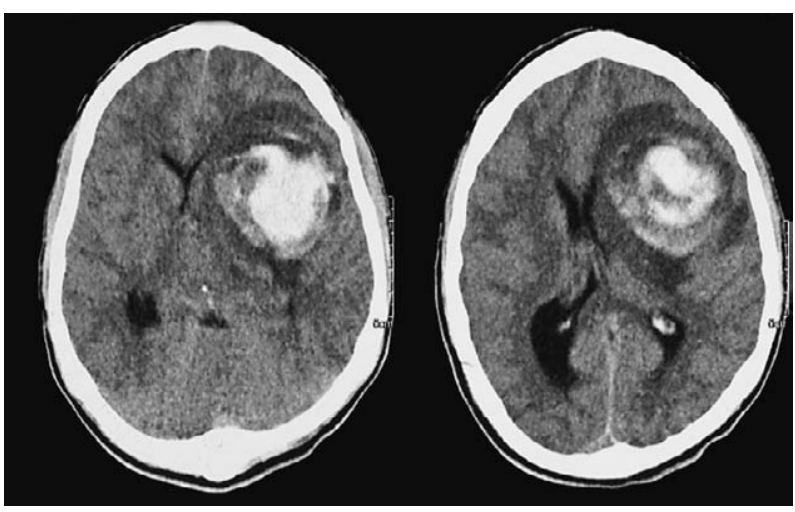

Fig. 2. Follow-up computed tomography scan after deterioration: enlargement of the hyperdense lesion with enlarged zone of edema and midline shift.

Computed tomography angiography revealed no finding that could indicate the existence of vascular pathology (Fig. 3).

Emergency surgery was performed and the lobed grayish lesion was entirely removed through the transcortical approach. Based on the macroscopic appearance, the surgeon assumed it was a metastasis of melanoma.

The patient was fully restituted and the postoperative course was uneventful. Follow-up CT revealed the expected postoperative changes with complete lesion removal (Fig. 4).

Histopathologic analysis showed dilated, thinwalled vascular spaces with intervening brain tissue showing edema, reactive gliosis and groups of hemosiderin-laden macrophages, so the final result was cavernoma (Fig. 5). 


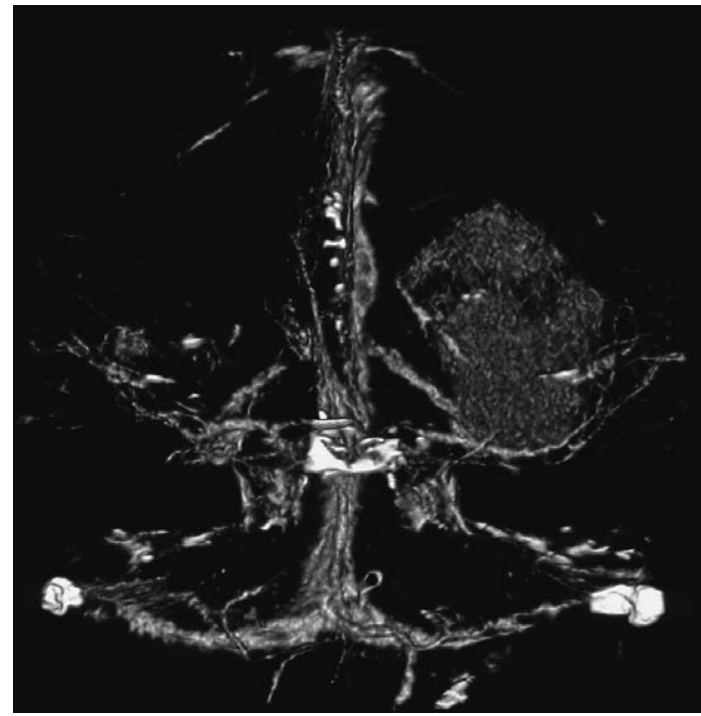

Fig. 3. Computed tomography angiography: vascularized lesion with no signs of any vascular malformations.

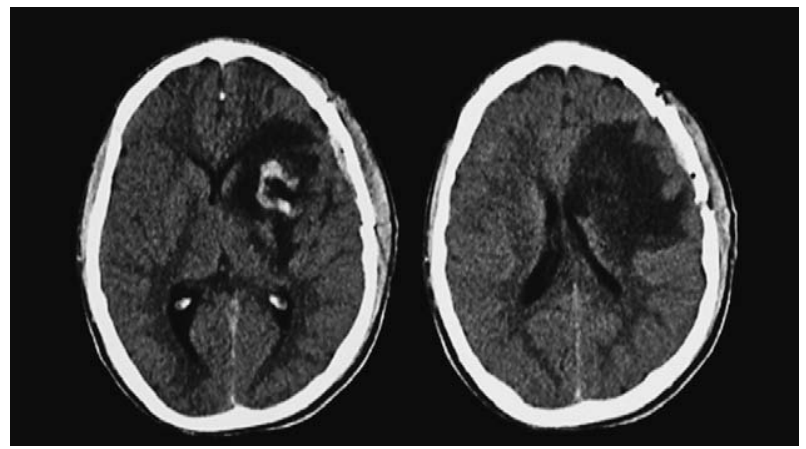

Fig. 4. Postoperative computed tomography scan: completely removed lesion with a significant midline shift reduction.

\section{Discussion}

This case is unique for the unusual (seizure-less) clinical presentation, rapid deterioration and typical intra-tumor hemorrhage appearance on CT, as well as for the emergency surgical treatment, which is rarely needed in cavernoma cases, especially the giant ones.

Although bleeding from a cavernoma is expected in the third and fourth decades of life, bleeding in GCs is more likely to occur in small children ${ }^{5,10,11}$, as well as at the age similar to our patient ${ }^{15}$. Localization was typical, as the majority of GCs found in the literature were located in the frontoparietal region ${ }^{3,6}$.

The clinical course in this case was quite untypical because mild symptoms had lasted for only three days

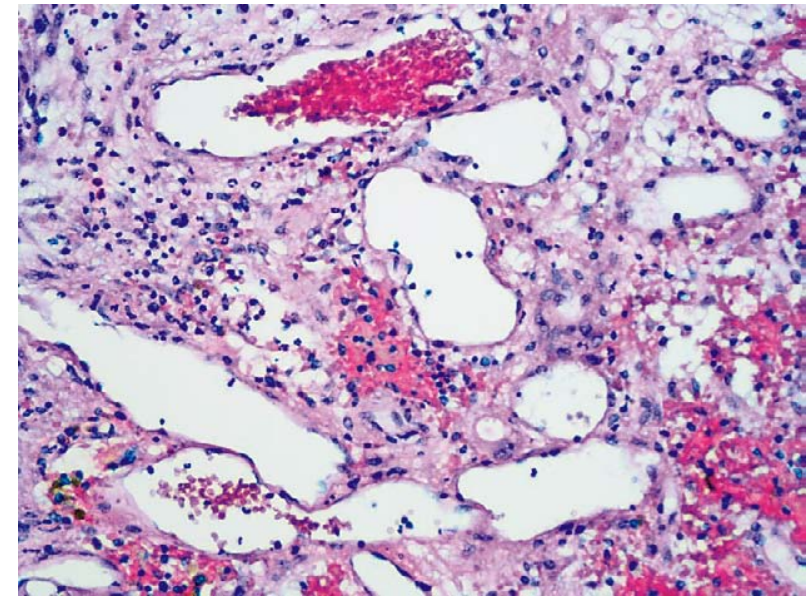

Fig. 5. The image shows dilated, thin-walled vascular spaces with intervening brain tissue showing edema, reactive gliosis and groups of hemosiderin-laden macrophages.

before admission. It is uncommon that a lesion that big in size did not cause any symptoms for a long time; the more so, the patient did not have any epileptic seizures, which is also uncommon for GC cases $^{1,3,6}$. Focal symptoms usually are not related to GCs and bleeding, but rather to a tumor or stroke. On the other hand, around $20 \%$ of GCs will present with a focal deficit ${ }^{15}$.

Rapid deterioration in our patient could be easily explained by massive bleeding inside GC after histopathologic confirmation, but intratumoral hemorrhage is by far more common in clinical practice and a typical pitfall in cases alike $6,7,11$.

While the common size cavernomas do not present a diagnostic dilemma ${ }^{2,6,18}$, GCs can have very heterogeneous CT presentation ${ }^{19}$. Therefore, distinguishing $\mathrm{GC}$ is quite challenging. ${ }^{9}$ CT appearance of $\mathrm{GC}$ in our case was a hemorrhagic hyperdense lesion with mass effect and perifocal edema, which is usual but not specific for GC, and much more frequently seen in tumors ${ }^{3,6,9,19}$. Misdiagnosing a GC as oligodendroglioma due to post-hemorrhagic calcifications, as anaplastic or pilocytic astrocytoma due to the isodense appearance with poor contrast enhancement, as ependymoma or even metastatic melanoma with intratumoral hemorrhage has been reported ${ }^{3,5}$. Other vascular malformations, as well as some infectious diseases, inflammatory nodules or granulomas have also been considered ${ }^{12,17}$. Rarely, a GC might present with indistinct margins and mimic glioma ${ }^{13}$. 
Computed tomography angiography was not helpful either, as cavernomas are angiographically occult lesions ${ }^{2,3}$. In case of bleeding GCs, imaging shows a nonspecific finding of the hypervascularized lesion. Digital subtraction angiography was not planned, and it is also considered redundant in these cases ${ }^{9,20}$.

Typical MRI finding with hyperintensity on T1weighted images and heterogeneous cystic appearance with multiple hemosiderin rings on T2-weighted images is quite specific, and might be helpful in unclear cases $^{15,19}$. Extra-axial GCs may be misunderstood as meningiomas, even on MRI due to similar characteristics ${ }^{8,9}$. Spectroscopy may provide additional details for distinguishing cavernomas in these cases ${ }^{19}$. Although MRI could have corrected our false impression, due to the patient's rapid worsening, emergency surgery was performed based on the CT finding.

Complete or gross total resection is the surgical principle in the treatment of GCs (as it is for the other tumors we suspected) if it is possible due to localization or association with a venous anomaly ${ }^{2,3,6}$. Besides the mass effect, indications for surgery are recurrent hemorrhages, drug-resistant epileptic seizures, and focal or progressive neurological deficit ${ }^{3,5,11,15}$. Emergency surgery is usually not indicated in order to avoid the possible intraoperative complications. This is achieved through detailed preoperative evaluation, which allows for the use of the dissection plane to avoid rebleeding, the finding of large feeders to prevent intraoperative hemorrhage, and preservation of the associated venous anomaly to prevent venous infarction ${ }^{21,22}$.

Although it is a rationale that GCs are associated with a worse prognosis, the location of cavernoma is more important than their size $\mathrm{e}^{11,23}$. The overall outcome is usually excellent, especially if seizure control is achieved $^{3,7}$. If seizures persist postoperatively, the outcome is considered less good.

\section{Conclusion}

Emergency surgery for mass lesions is not uncommon in neurosurgery, however, bleeding cavernomas are usually planned for elective surgery due to the specific surgical treatment timing and approach, as well as due to the possible intraoperative bleeding and/or associated anomalies that may sometimes turn out difficult to control.

Although our case went relatively straight-forward regardless of insufficient preparation, GCs have to be considered as an option, especially in the young age population, demanding careful preoperative planning, as their treatment might turn out to be more complicated than expected.

\section{References}

1. Agrawal A, Banode P, Shukla S. Giant cavernous hemangiomas of the brain. Asian J Neurosurg. 2012;7(4):220-2. Epub 2013/04/06. doi: 10.4103/1793-5482.106660. PubMed PMID: 23559993; PubMed Central PMCID: PMCPMC3613648.

2. Chicani CF, Miller NR, Tamargo RJ. Giant cavernous malformation of the occipital lobe. J Neuroophthalmol. 2003;23(2): 151-3. Epub 2003/06/05. doi: 10.1097/00041327-20030600000010 PubMed PMID: 12782930.

3. Jhawar S, Nadkarni T, Goel A. Giant cerebral cavernous hemangiomas: a report of two cases and review of the literature. Turk Neurosurg. 2012;22(2):226-32. Epub 2012/03/23. doi: 10.5137 /1019-5149.JTN.2903-10.1. PubMed PMID: 22437298.

4. Houtteville J-P. Brain cavernoma: a dynamic lesion. Surg Neurol. 1997;48(6):610-4. doi: 10.1016/s0090-3019(96)00551-4.

5. Sharma A, Mittal RS. A giant frontal cavernous malformation with review of literature. J Neurosci Rural Pract. 2016;7(2): 279-82. Epub 2016/04/27. doi: 10.4103/0976-3147.178666. PubMed PMID: 27114662; PubMed Central PMCID: PMCPMC4821939.

6. Son DW, Lee SW, Choi CH. Giant cavernous malformation: a case report and review of the literature. J Korean Neurosurg Soc. 2008;43(4):198-200. Epub 2008/12/20. doi: 10.3340/ jkns.2008.43.4.198. PubMed PMID: 19096644; PubMed Central PMCID: PMCPMC2588260.

7. van Lindert EJ, Tan TC, Grotenhuis JA, Wesseling P. Giant cavernous hemangiomas: report of three cases. Neurosurg Rev. 2007;30(1):83-92; discussion Epub 2006/09/22. doi: 10.1007/ s10143-006-0042-8. PubMed PMID: 16988810.

8. Pelluru PK, Rajesh A, Uppin MS. Dural-based giant cavernous hemangioma mimicking a meningioma: lessons learnt. Neurol India. 2017;65(5):1173-6. Epub 2017/09/08. doi: 10.4103/ neuroindia.NI_1151_15.PubMed PMID: 28879931.

9. Lan Z, Richard SA, Li J, Xu J, You C. A giant solid cavernous hemangioma mimicking sphenoid wing meningioma in an adolescent: a case report. Medicine (Baltimore). 2018;97 (44):e13098. Epub 2018/11/02. doi: 10.1097/MD.0000000 000013098. PubMed PMID: 30383694; PubMed Central PMCID: PMCPMC6221700.

10. Villasenor-Ledezma J, Budke M, Alvarez-Salgado JA, Canizares MA, Moreno L, Villarejo F. Pediatric cerebellar giant cavernous malformation: case report and review of literature. Childs Nerv Syst. 2017;33(12):2187-91. Epub 2017/07/27. doi: 10.1007/s00381-017-3550-7. PubMed PMID: 28744689.

11. Villalonga JF, Saenz A, Campero A. Surgical treatment of an asymptomatic giant supratentorial cavernous hemangioma. Case report.J Clin Neurosci. 2019;62:231-4. Epub 2019/01/09. doi: 10.1016/j.jocn.2018.12.032. PubMed PMID: 30616875. 
12. Ozsoy KM, Oktay K, Gezercan Y, Cetinalp NE, Olguner SK, Erman T. Giant cavernous malformations in childhood: a case report and review of the literature. Pediatr Neurosurg. 2017;52(1):30-5. Epub 2016/07/19. doi: 10.1159/000447407. PubMed PMID: 27427970.

13. Boschi A, Consoli A, Buccoliero A, Barbagli G, Mangiafico S, Ammannati F. Left deep frontal cavernous angioma mimicking a glioma in an adult patient. Asian J Neurosurg. 2018;13 (4):1233-5. Epub 2018/11/22. doi: 10.4103/ajns.AJNS_124 _17. PubMed PMID: 30459903; PubMed Central PMCID: PMCPMC6208243.

14. Tripathy LN, Singh SN. Multiple giant cavernous angiomas of the brain. Neurol India. 2009;57(3):350-1. Epub 2009/07/10. doi: 10.4103/0028-3886.53267. PubMed PMID: 19587484.

15. Wang C, Zhao M, Wang J, Wang S, Zhang D, Zhao J. Giant cavernous malformations: a single center experience and literature review.J Clin Neurosci. 2018;56:108-13.Epub 2018/07/10. doi: 10.1016/j.jocn.2018.06.042. PubMed PMID: 29983331.

16. Lawton MT, Vates GE, Quinones-Hinojosa A, McDonald WC, Marchuk DA, Young WL. Giant infiltrative cavernous malformation: clinical presentation, intervention, and genetic analysis: case report. Neurosurgery. 2004;55(4):979-80. Epub 2005/06/07. doi: 10.1227/01.neu.0000137277.08281.48. PubMed PMID: 15934180.

17. Mohindra S, Sodhi HS, Rane S. Tumefactive presentation of a supratentorial cavernous hemangioma: a report of two cases. J Pediatr Neurosci. 2013;8(3):232-4. Epub 2014/01/29. doi: 10.4103/1817-1745.123689. PubMed PMID: 24470821; PubMed Central PMCID: PMCPMC3888044.
18. Jin SC, Ahn JS, Kwun BD, Kwon DH. Intraventricular cavernous malformation radiologically mimicking meningioma. J Korean Neurosurg Soc. 2008;44(5):345-7. Epub 2009/01/03. doi: 10.3340/jkns.2008.44.5.345. PubMed PMID: 19119474; PubMed Central PMCID: PMCPMC2612575.

19. Kan P, Tubay M, Osborn A, Blaser S, Couldwell WT. Radiographic features of tumefactive giant cavernous angiomas. Acta Neurochir (Wien). 2008;150(1):49-55; discussion Epub 2007/ 12/11. doi: 10.1007/s00701-007-1455-z. PubMed PMID: 18066488 .

20. Milatovic B, Tasic G, Nikolic I, Doric I, Repac N, Scepanovic $\mathrm{V}$, et al. Determination of predictive anatomic parameters for bleeding of brain arteriovenous malformations by multidetector CT angiography. Acta Clin Croat. 2017;56(4):728-32. Epub 2018/03/30. doi: 10.20471/acc.2017.56.04.21. PubMed PMID: 29590729.

21. Arraez MA, Ros B, Arraez C. Complications of the Surgery for Cavernomas. Complications in Neurosurgery: Elsevier; 2019. p. 64-9.

22. Rasulic L, Vitosevic F, Rotim K, Milosevic Medenica S, Nestorovic D. Developmental venous anomaly serving as a draining vein of brain arteriovenous malformation. Acta Clin Croat. 2017;56(1):172-8. Epub 2017/11/10. doi: 10.20471/acc.2017. 56.01.24. PubMed PMID: 29120564.

23. Rotim K, Sajko T, Skoro I, Zmajevic-Schonwald M, Boric M. Complete neurological recovery after surgery for mesencephalic cavernoma: case report. Acta Clin Croat. 2014;53(4):494-8. Epub 2015/04/15. PubMed PMID: 25868320.

Sažetak

\title{
DIVOVSKA KAVERNOZNA MALFORMACIJA S NEUOBIČAJENO AGRESIVNIM KLINIČKIM TIJEKOM: PRIKAZ SLUČAJA
}

\author{
J. Grujic, V.Jovanovic, G. Tasic, A. Savic, A. Stojiljković, S. Matic, M. Lepic, K. Rotim i L. Rasulić
}

Divovski kavernomi (DK) su rijetke lezije s manje od 50 dosad opisanih slučajeva. Uobičajena simptomatologija su epileptični napadaji, a rjeđe se manifestiraju žarišnim neurološkim deficitom koji je uzrokovan ponavljanim hemoragijama i posljedičnim povećanjem intrakranijskog tlaka. Iako su objavljeni pojedini slučajevi, zbog rijetke pojavnosti i raznovrsne radiološke prezentacije DK se obično ne razmatraju u diferencijalnoj dijagnostici velikih hemoragičnih ekspanzivnih lezija, pogotovo kada je prisutan značajan kompresivni učinak. Sedamnaestogodišnji dječak se javio liječniku zbog jake glavobolje, blaže desnostrane slabosti i nerazgovijetnog govora. Simtpomi su se javili 3 dana ranije u vidu blagih glavobolja koje su se postupno pojačavale. Hitna kompjutorizirana tomografija je pokazala masivnu hemoragičnu leziju frontalno lijevo. Nedugo zatim desnostrana slabost i nerazgovijetan govor su se pogoršali i bolesnik je postao pospan s blago proširenom lijevom zjenicom. Učinjena je hitna operacija, kružna sivkasta lezija je u cijelosti uklonjena. Na osnovi makroskopskog izgleda kirurg je pomislio da se radi o metastazi melanoma. Histopatološka analiza je pokazala da se radi o kavernomu. DK bi trebalo razmatrati kao mogućnost kod hemoragičnih lezija, pogotovo kod mlađih bolesnika. Hitna operacija kod kompresivnih lezija nije rijetkost u neurokirurgiji, međutim, krvareći kavernomi se obično planiraju za elektivnu operaciju zbog specifičnog pristupa i mogućih komplikacija.

Ključne riječi: Hemangiom, kavernozni; Intrakranijsko krvarenje; Intrakranijski tlak; Pareza; Neurokirurgija 